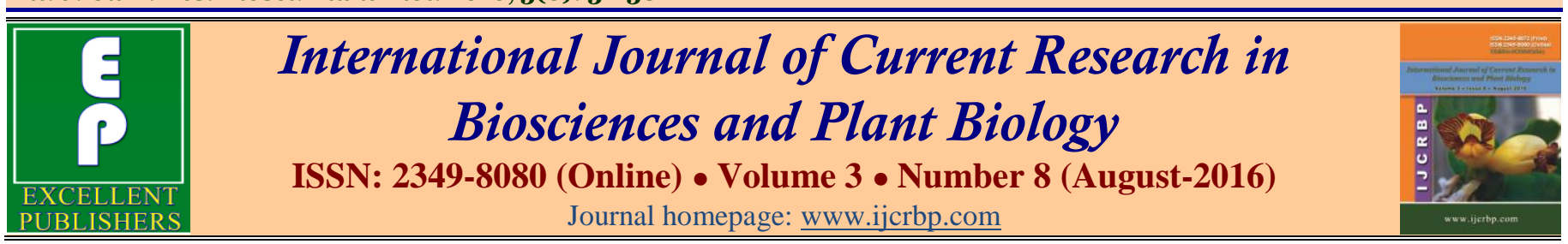

\title{
The Unsustainable Exploitation of Wildlife-Habitat Resources in Tubah Sub-Division, Northwest Region, Cameroon
}

\author{
Melle Ekane Maurice*, Nkwatoh Athanasius Fuashi, Achiri Akere Bell and \\ Terence Njopin Hele \\ Department of Environmental Science, Faculty of science, University of Buea, P. O. Box 63, Cameroon \\ *Corresponding author.
}

\section{A bstract}

There has been rampant encroachment on Cameroons protected forest landscapes in the last few years. This has resulted to the loss of substantial parts of the forest cover through cultivation for agriculture, settlements, charcoal processing, logging and hunting. The principal target group for this research was the local forest community in and around Tubah Upland Forest who wrestle their living from this forest. The data collection involved an oral interview and questionnaire administration. The results showed that Gender and the awareness of wildlife laws in Tubah region correlated significantly $\left(\mathrm{r}^{2}=0.726\right.$ at $\left.p<0.05\right)$ gender. Also, the importance of forest resources had a significant correlation with solutions to wildlife conflict $\left(\mathrm{r}^{2}=0.379\right.$ at $\left.p<0.05\right)$. In addition, the reason for settlement also had a significant relationship with organizations mitigating human-wildlife conflict $\left(\mathrm{r}^{2}=0.863\right.$ at $\left.p<0.05\right)$ with NGO'S such as CIRMAD (The Care for Indigenous Resources Management and Development) working to raise conservation awareness in the area. Furthermore, the investigation on the importance of forest resources recorded $67.88 \%$ on forest exploitation. Edible plants rich in protein accounted for $16.57 \%$ in the survey. Moreso, the solutions to human-wildlife conflict also recorded $77.78 \%$, confirming very little help is given to local people by the government authorities. Finally wildlife contact rate recorded $11.52 \%, 8.08 \%, 44.24 \%$, and $36.16 \%$ respectively for very frequent, infrequent, frequent, and no contact rates. This survey revealed the importance of the corporation and integration of the local community in forest conservation decision-making.
\end{abstract}

\section{Article Info}

Accepted: 13 July 2016

Available Online: 06 August 2016

Keywords

Encroachment

Forest community

Protected areas

Wildlife conservation

Wildlife laws

\section{Introduction}

The process of deforestation is the destruction of indigenous forests and woodlands. It is the conversion of the forest into another land use or the long-term reduction of the tree canopy cover below the minimum ten percent threshold (FAO, 2001). This loss of forest cover has been on the increase worldwide for some time now particularly during the nineteenth and twentieth century. Historically, deforestation started with the advent of sedentary agriculture, prior to which 40 percent of the world's land area or 6000 million hectares were covered with forests. This was over 8000 years ago and since then farms, pastures and settlements have claimed most of the world's forest lands (Roberts and Rodger, 1999). At the beginning of the Christian era, removal of forests was well advanced in Mesopotamia and the Mediterranean Basin. Later the industrial revolution in Europe put tremendous pressure on forests as a source of fuel and railway sleepers and this occurred further wherever industries were introduced in the world. As Rowe et al. (1992) explains, between 1850 and 1980, 
$15 \%$ of the world's forests and woodlands were cleared. In modern times, this destruction of forests has even intensified and become widespread. For example in its latest ten-year periodical assessment of world forests, the Food and Agriculture Organization (FAO) in 2000 estimated that the global loss of natural forest cover during the 1990s was 16.1 million hectares per year of which 15.2 million hectares per year were being lost in the tropics. During the decade under review, deforestation is said to have been highest in Africa and southern America and individual countries with the highest net loss during the same decade included Argentina, Brazil, Democratic Republic of Congo (former Zaire), Zambia and Zimbabwe. FAO further estimated that 56,000 hectares of tropical forests are destroyed each day worldwide and if this rate continued, it would only take 177 years to clear all tropical rain forests (FAO, 2001).

Most of the world's forests are in open landscapes with no restrictions on use as only around 8 to 12 percent of the world tropical forests are in parks and reserves (FAO, 2001). In its Forest Resources Assessment 2000 referred to above, FAO estimated that the world forests cover by 1999 had been reduced from 6000 million hectares in the 1850 s to 3500 million hectares. This loss is attributed to human exploitation, and most of this clearance occurred in the latter half of the twentieth century (FAO, 2001). The global distribution of deforestation is such that it is generally more serious in developing countries of Latin America, Asia and Africa than in the developed world (World Resources Report, 1996).

Generally, the most significant issues are continued deforestation and an insufficient capacity or consideration of governments to sustainably manage their forests. Following this, there are extensive dialogues on the type of roles and approaches that government should consider in the administration of forests. Many of the contemporary positions suggest making forest management more responsive to the needs of local people (Mazur and Stakhanov, 2008). These voices have called for a more decentralized approach to forest management, with greater control over forest resources placed in the hands of the local users most closely associated with the forestlands. Indeed, many African countries made significant changes to their forest policies in the 1990s and, at the urging of many in the forestry and development communities, adopted provisions that allow for some level of local community involvement in small areas of local forests. One forest management case that reaped success with its local community involvement is that of the Kilim-Ijim Forest Project. As documented by Mvondo (2009), conservation was achieved using a participatory approach that found alignment between the community's desires and the conservation objectives of the NGO, Bird Life International. The process was quickly embraced by the communities, which strengthened their local organization and took active roles in advancing the partnership program. Conservation continues today, and even boasts an increase in the extent of the forest. Still, Gardner does acknowledge that the situation may not be replicable in communities with more conflict, or less perceived-value placed on their forest resources.

\section{Materials and methods}

\section{Description of the study area}

Tubah subdivision is found in the North West Region of Cameroon, located about $15 \mathrm{~km}$ from Bamenda, the Regional capital. It consists of four main villages Bambili, Bambui, Kedjom-keku and Kedjom-ketingoh, and it is located between latitude $4^{\circ} 50^{\prime}-5^{\circ} 20^{\prime} \mathrm{N}$ and longitude $10^{\circ} 35^{\prime}-11^{\circ} 59^{\prime} \mathrm{E}$ with a total population of about 52635 inhabitants. The altitude ranges between 950-1500 m above sea level, with flat woody lowland in some areas. Its forested area is located in the northern part of the subdivision. The drainage system is very rich with streams and springs emanating from the northern belt. The zone has two seasons, the dry and wet seasons range from November-April and May-October respectively. The mean annual rainfall is about $2200 \mathrm{~mm}$ with July, August and September registering the highest rainfall and December the lowest. Also, the mean annual temperature is about $20.67^{\circ} \mathrm{C}$ with January and February registering the highest and July, August and September the lowest temperature (Yuninui, 1990). Unsustainable farming practices have largely destroyed the forest vegetation to an extent and depleted soil fertility. Similarly, years of overgrazing, burning of grasses, and increasing herd size, have has severely degraded the remaining patches of grasslands.

The present vegetation of Tubah consists mainly savannah ecosystem, with the Poaceae of Grammeae plants forming the main vegetation layer interspersed with a few other annuals, perennials and trees. According to Ngwa and Fonjong (2002a), the vegetation of this region is both natural and cultivated. The cultivated vegetation consists of planted trees like cola nut, eucalyptus, raffia palm and other fruit trees. 


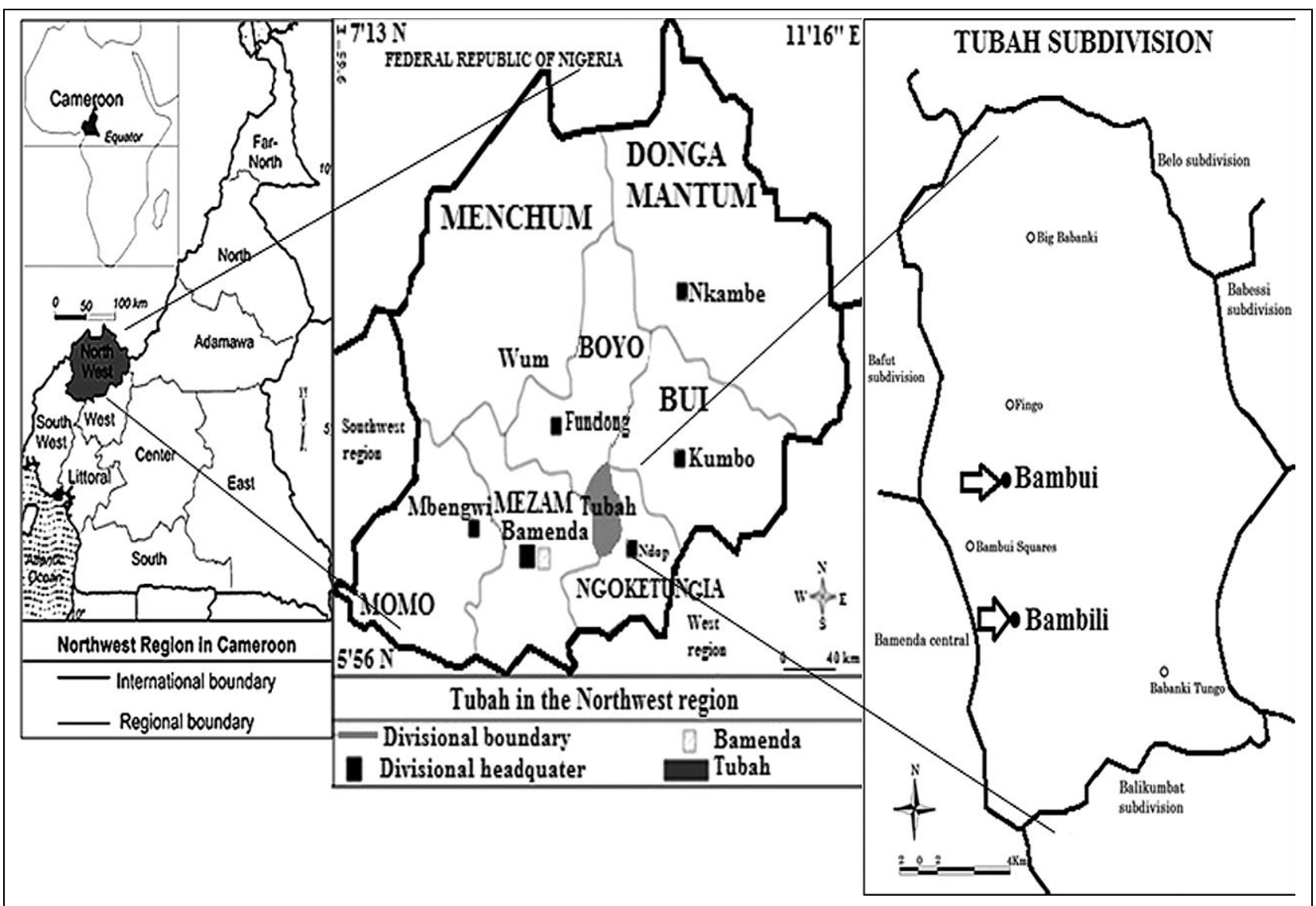

Fig. 1: Map of Tubah Sub Division, Northwest Region, Cameroon (Source: Ngwa and Fonjong, 2002a).

\section{Data collection}

Data collection consisted of two sampling techniques: Purposive sampling and simple random sampling. Purposive sampling was used to allocate communities targeted for the study. Four major communities were selected, Bambili, Bambui, Kedjom-keku and Kedjomketingoh from six different areas during the study. These communities have been assessed to be among the communities having the greatest human influence on the forest resources of the study area, due to their relative high population size, household size, and proximity to available forest resources (Ajabji et al., 2008). The language used in administering these questionnaires was the local dialect which is being spoken across the six villages. A planning meeting was organized in each of the target communities prior to the beginning of the study to explain the aims of the study. This facilitated the clarity and purpose of the study and encouraged respondents to open up during questionnaire administration of systematic randomly selected respondents. In the second step, the main statistical method for questionnaire administration was systematic random sampling (Mvondo, 2009). Questionnaires administration was supplemented with focus group discussions, interviews and field observations. Questionnaires were used to survey the selected local communities in order to identify the main users of forest resources. The survey was conducted also with a face-toface interview in which the interviewer filled in the questionnaire based on the respondent's answer. This approached helped to minimize misunderstanding of questions by the respondents, increasing the reliability of collected information. A total number of 500 questionnaires were administered to the respondents during the survey. All age groups from teenage to adult were considered during the interviews and questionnaire administration in order to reduce bias in the study.

\section{Results and discussion}

The The awareness of wildlife laws in the community has a positive correlation $\left(\mathrm{r}^{2}=0.726\right.$ at $\left.p<0.05\right)$ with gender (Table 1). Growing evidence points to the fact that members of this rural community do not have the same sets of shared concerns. Also, there is a (Fig. 2) correlation between the importance of forest resources and the survival of wildlife $\left(\mathrm{r}^{2}=0.379\right.$ at $\left.p<0.05\right)$. The 
forests biodiversity is a key function of human survival in Tubah sub division. The richer the forest biodiversity, the greater the opportunity for medical discoveries, economic development and adaptive responses to new challenges such as climate change in this community. Fig. 3 shows a correlation between the organization mitigating human-wildlife conflict and the healthy survival of the community $\left(\mathrm{r}^{2}=0.863\right.$ at $\left.p<0.05\right)$.

Table 1. Gender and the awareness of wildlife laws.

\begin{tabular}{llllll}
\hline Symmetric Measures & & Value & $\begin{array}{l}\text { Asymp. Std. } \\
\text { Error }^{\mathbf{a}}\end{array}$ & Approx. T & Approx. Sig. \\
\hline Interval by Interval & Pearson's R & -0.016 & 0.045 & -0.351 & $0.726^{\mathrm{c}}$ \\
Ordinal by Ordinal & Spearman Correlation & -0.018 & 0.045 & -0.394 & $0.694^{\mathrm{c}}$ \\
N of Valid Cases & & 495 & & & \\
\hline
\end{tabular}

${ }^{a}$ Not assuming the null hypothesis; ${ }^{b}$ Using the asymptotic standard error assuming the null hypothesis; ${ }^{c}$ Based on normal approximation.

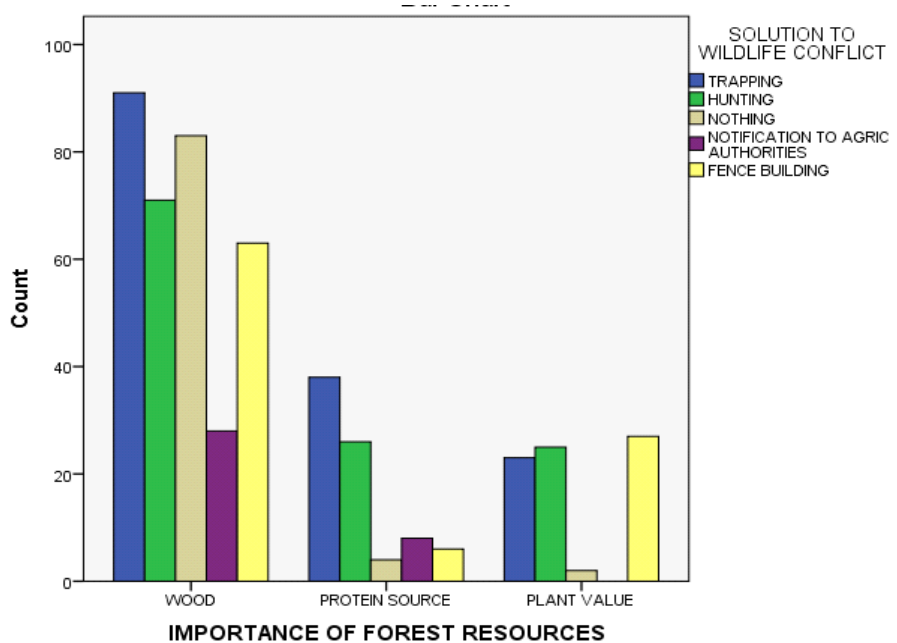

Fig. 2: Importance of forest resources and solution to wildlife conflict.

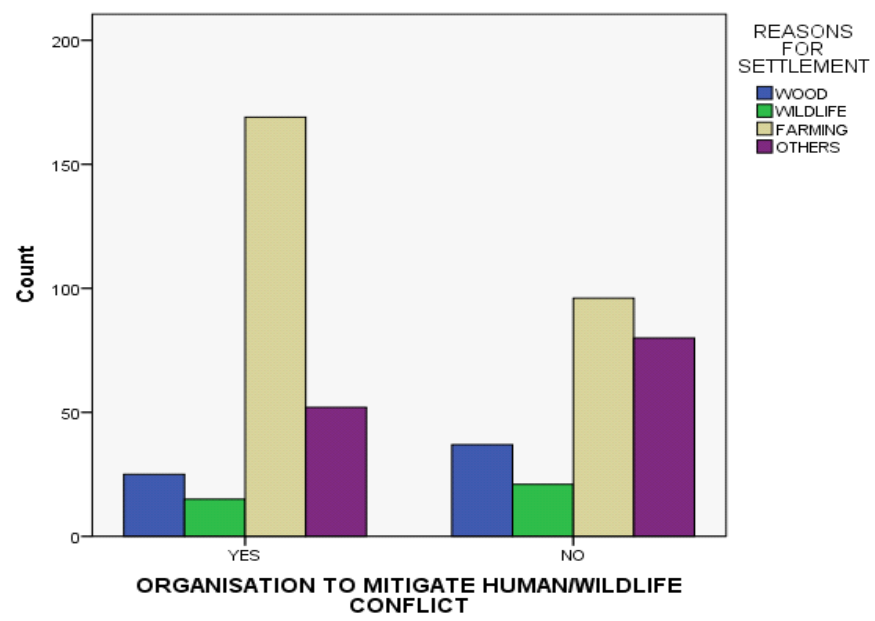

Fig. 3: Reasons for settlement and organization to mitigate human wildlife conflict.

Adult men, women and other social groups may have conflicting and complimentary interest in relation to wildlife resources (Table 1). They all have access to the forest and their wildlife resources. The wildlife contact rate recorded $11.52 \%, 8.08 \%, 44.24 \%$, and $36.16 \%$ respectively for very frequent, infrequent, frequent, and no contact rates (Fig. 4). More so, the investigation on importance of forest resources revealed that wood exploitation recorded $67.88 \%$, and edible plants rich in protein accounted for $16.57 \%$ in the survey (Fig. 5). However, the types of product they gather or collect from this forest are different. Usually, products collected by women end up in the household either directly or indirectly, while the men usually end up using their earnings privately. Thus, women perceive the forest as sources of goods and services to support the household, and the men perceive it as sources of finance. Most women use their forest produce to support household needs and this is also true for many men. The income gained from the sale of the forest wildlife products are put into the household management. Benefits from forest and wildlife resources depend very much on all the above factors. Since men outnumber women, when it comes to economic gains one may conclude that men benefit more from forest and wildlife resources than their women counterparts (Enchaw, 2009). Both men and women in the study region are uneducated and as such are not aware of the Cameroon forestry and wildlife laws, though effort presently is put in place by some Non Governmental Organizations such as CIRMAD to educate the locals on these laws. Illegal hunting and related illegal trade of wildlife are the most immediate threats to many wildlife populations in this area, carried out mostly by the males in order to meet up with economic gains. The government has put in place protected areas programs such as sensitization of the indigenes on the need to conserve the forest. These programs are usually held at the village squares where the villagers and some stakeholders advise them on needs, to conserve their forest. 


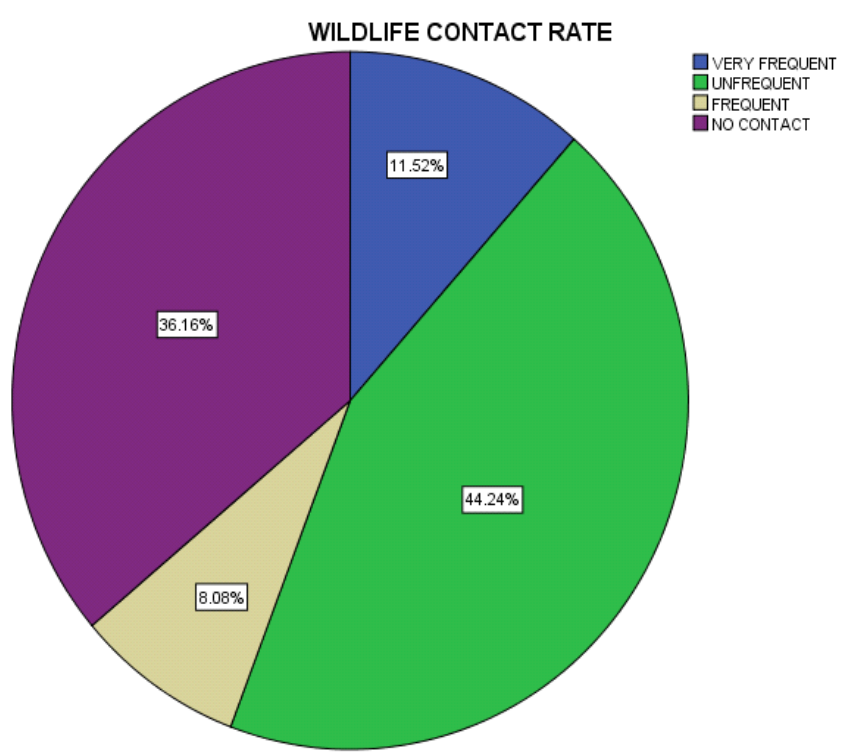

Fig. 4: Wildlife contact rate.

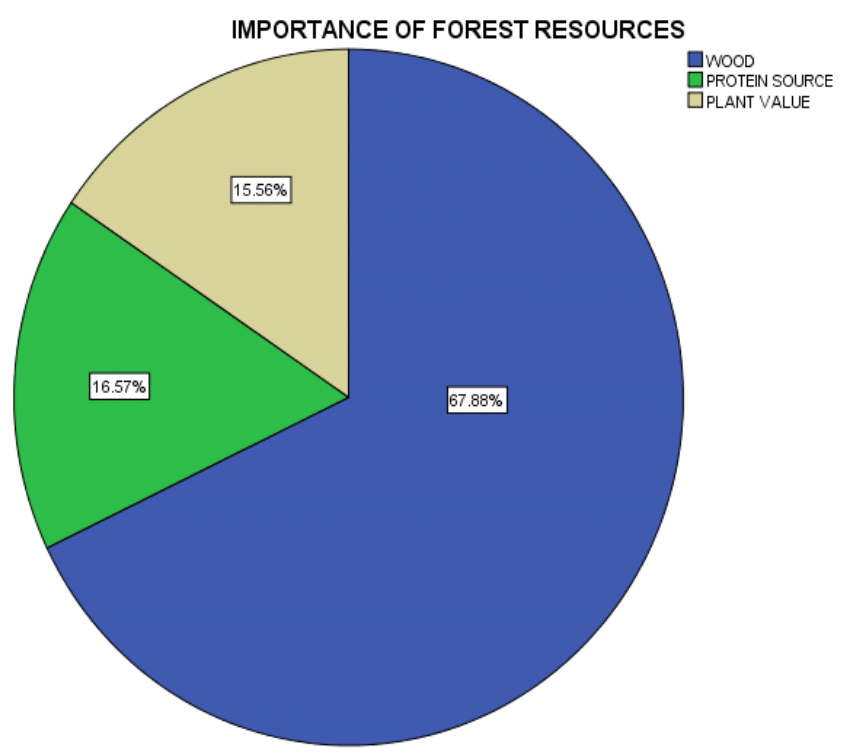

Fig. 5: Importance of wildlife resources.

Another measure put in place to ensure effective conservation of the forest is the development of an environment sectoral program by the government. This program provides space for local participation in forest processes and has helped in the conservation of the rainforest. Based on this approach, local people within the community participate in benefit sharing. Therefore, the government has moved towards increasing participation of indigenes through local communitylinked processes in which government agencies are involved. Also, the existence of rainforest management institutions in some forest communities has made the people participate in forest management activities, the most important being the prevention of forest fires.
The rainforests is an extremely important natural resource (Fig. 2) that can potentially and sustainably be harvested and managed to yield a diversity of commodities of economic importance (Blomley, 2013). Wood is by far the most important product harvested from the Tubah upland forest. Firewood is their major source of energy used for cooking and other purposes. Potentially, all of these forest products can be sustainably harvested. Unfortunately, in most cases forests have been unsustainably overharvested, resulting to a widespread ecological degradation (Brosious, 2000). It is critical to understand that in future all forest-resource gathering and harvesting is conducted in a more responsible and sustainable manner. Many other forest resources are also collected from this area, such as fruits, nuts, mushrooms, and latex for producing local rubber. In addition, many species of animals are hunted in forests for subsistence. This forest provides additional goods and services that are important to both human welfare and to ecological integrity, including the control of erosion and water flows, and the cleansing of air and water pollutant (Blomley, 2013). There are a variety of adopted ways the local population here handles wildlife conflict: Farmers have learned to build wire-fences to protect crops from being eaten. Several farmers have now dug fish ponds in front of the fences as added barriers. These ponds do not only reduce the wildlife raids, but also generate new income by allowing farmers to raise fish alongside their crop-farming. Scarecrows are put in place to repel away birds, rodents, mammals from eating crops (FAO, 1999). However, some individual even claimed they kill these animals as revenge. They also claim that help is not offered by the government authorities to solve this problem.

Furthermore, majority of individuals indicated that the wildlife contact rate is frequent (Campbell, 1995). One of the main reasons is the rapid encroachment of the expanding human population into the natural habitats of these wildlife animals. Farming activities carried out deep into the forest where these animals inhabit bring humans more closely to the wildlife (FAO, 1999). Forests once largely covered the Bamenda Highlands region of Cameroon. However, the forests were progressively cleared for farmland and grazing until today only patches remains. Although small, these patches are recognized as globally important sites for conservation of biological diversity. At the same time, the forests are very important for the people living around them, as they supply water, fuel wood, medicines, honey and other products and have cultural and spiritual importance (Ngwa and Fonjong, 2002b). 
The montane forests of the Bamenda Highlands region are unlike other forested areas of Cameroon where there is high potential for income generation through timber exploitation and where community forestry is often seen as a means of redirecting some of these benefits towards community development. Instead, in the Bamenda Highlands region, community forestry has developed as a partnership between the conservation community, which is interested in conservation of biological diversity, and the local population, which is interested mainly in the various benefits to be derived from the forest.

There is an organization working to mitigate humanwildlife conflict called CIRMAD in this area. However, majority of the local people are unaware of this Nongovernmental organization which supposed to help in advising them on how to mitigate conflicts with wildlife. In Fig. 3, the survey revealed that $52.73 \%$ of these individuals affirmed the existence of this organization and its capability in solving this problem. It can also be acknowledged that more than half of the population of these individuals here are aware of the presence of this organization. One of the reasons this organization is not recognized by some of the local people here is because it lacks the adequate funds to run properly, hence it cannot be efficient and effective to meet their expectations (Enchaw, 2009).

More so, another committed member of this partnership is the Ministry of Forestry and wildlife. In the bid for sustainability of ecological stability and prevention of species decline, the Cameroon Ministry of Forestry and wildlife has since 2008 created six categories of protected areas (National Parks, Zoological Gardens, Wildlife Sanctuaries, Fauna and Flora). This successful partnership started with the Kilum-Ijim Forest Project (KIFP), which focused on the conservation of the KilumIjim Forest, the largest of the remaining forest patches, through the development of a system of communitybased management. Seeing the success of community forestry at Kilum-Ijim, other communities also started to request assistance to manage their forests, as a result of this, other forest communities came into existence, such as the Kimbi foresrt, the Dom forest, and Oku forest These collaborative efforts resulted into the development of the Bamenda Highland Forestry Project (BHFP), which works throughout the Bamenda Highlands region with communities interested in conserving and managing their forest. Response to this project has been overwhelming. As the new project provides mostly technical advice, with very limited material inputs, the incentive for forest management appears to be coming from the communities themselves (Enchaw, 2009).

\section{Conclusion}

This survey has revealed that there are several anthropogenic factors that have resulted to the encroachment of this rainforest. Some of these reasons include poverty, growing population, weak forest conservation laws. The local people are not participating in a meaningful way in the management of forest resources in this part of the country due to their poor relationship with the forest department officials and NGOs. The management of forest resources in the area and the country as a whole is largely still centralized by the Cameroon Government and therefore lacks the genuine support and contribution of the local people. This lack of understanding between the community and the national government has not only contributed to the encroachment and deforestation of this protected forest but has also weakened the spirit of proper rainforest management in other Regions in the country. Despite the achievements signs, there is still doubt that initial enthusiasm for community management of the forest may wane with time, as people become more familiar with the difficulties and effort required. While a permanent water supply and access to useful forest products are important benefits to be gained through forest management, there is a possibility that in the long term these are not enough for all communities to remain committed to the process. Serious management efforts are put in place to overcome the weaknesses and conservation threats of this forest zone. In enhancing this approach, much attention has been focus on the needs of the local people. Environmental awareness has been integrated in the conservation planning programmes. In this way, the local inhabitants can learn how to manage the wildlife and landscapes in a suitable manner, making sound livelihood decisions without sacrificing their cultural values. Some communities however in this area are undertaking activities such as serious planting of trees on the degraded are. This is another measure which has been put in place to ensure the conservation of biodiversity of the forest. In general, the forest is being managed for the conservation of biodiversity and sustainable use, something that did not happen in the past.

\section{Conflict of interest statement}

Authors declare that they have no conflict of interest. 


\section{References}

Ajabji, S., Tendem, P., Nkembi, L., 2008. A Socio-economic Report for the Bechati-Fossimondi-Besali Forest Adjacent Villages. Final Project Report submitted to WWF, Netherland, US Fish and Wildlife Service and Tusk Trust UK, Buea, Cameroon.

Blomley, T., 2013. Lessons Learned from Community Forestry in Africa and Their Relevance for REDD+. USAID-supported Forest Carbon, Markets and Communities (FCMC) Program. Cameroon $4^{\text {th }}$ National Report on the Convention on Biological Diversity. Washington, DC, USA. 49p.

Brosious, J. P., 2000. Endangered forests, endangered people: Environmentalist representations of indigenous knowledge. In: Indigenous Environmental Knowledge and its Transformations: Critical Anthropological Perspectives (Eds.: Ellen, R., Parkes, P., Bicker, A.). Overseas Publishers' Association, Amsterdam. pp.293-317.

Campbell, N. Y., 1995. Tailoring forest management systems to people's needs. In: Enabling Environment for Joint Forest Management: Forest Studies Series (Ed.: Roy, S. B.). Inter-India Publications, New Delhi. pp.59-86.

Enchaw, G. B., 2009. An Assessment of Conservation Strategies in the Management of Natural Resources in the Kilum-Ijim Forest Project Area (North of Cameroon), Unpublished Ph.D Thesis.

FAO, 1999. State of the World's Forests, Food and Agriculture Organisation, Rome. Deforestation continues at a High Rate in Tropical Areas. State of World's Forests, Food and Agriculture Organisation, Rome.
FAO, 2001. Global Forest Resources Assessment 2000: main report. Food and Agriculture Organisation Forestry Paper 140. Rome.

Mazur, E.M., Stakhanov, O.V., 2008. Prospects for enhancing livelihoods, communities and biodiversity in Africa through community based forest management: A critical analysis. Local Environ. 13(5), 405-421.

Mvondo, S. A., 2009. State failure and governance in vulnerable states: An assessment of forest law compliance and enforcement in Cameroon. Africa Today. 55(3), 85102.

Ngwa, N.S.E., Fonjong, L.N., 2002a. Absence of Incentive: Analyzing Potential for Collective Action for the Sustainable Management of the Upland Forest of Tubah Subdivision, NWR, and Cameroon by Brian Bragg.

Ngwa, N.S.E., Fonjong, L.N., 2002b. Actors, options and the challenges of forest management in Anglophone Cameroon. Geojournal, 57, 95-111.

Roberts, R. W., Rodger, J., 1999. Deforestation: Tropical Forests in Decline. Forestry Issues, British Columbia, CIDA.

Rowe, R., Sharma, N. P., Bowder, J., 1992. Deforestation: Problems, causes and concern. In: Managing the World's Forest: Looking for Balance between Conservation and Development (Ed.: Sharma, N. P.) Kendall/Hunt Publishing Company, Iowa. pp.33-46.

World Resources Report, 1996. World Resources: A Guide to the Global Environment 1996-1997. Oxford University Press, London. pp.56-90.

Yuninui, N.M., 1990. Initiation Practical Report on Bambili Village. A Research Report, Regional College of Agriculture, Bambili, Cameroon.

\section{How to cite this article:}

Melle, E.M., Nkwatoh, A.F., Achiri, A. B., Terence, N. H., 2016. The unsustainable exploitation of wildlifehabitat resources in Tubah sub-division, Northwest Region, Cameroon. Int. J. Curr. Res. Biosci. Plant Biol. 3(8), 32-38. doi: $\underline{\text { http://dx.doi.org/10.20546/ijcrbp.2016.308.005 }}$ 